\title{
EFFECT OF ALKALI TREATMENT ON THE TENSILE STRENGTH OF LIDAH MERTUA FIBER/ POLYPROPYLENE RECYCLED BIOCOMPOSITE
}

\author{
IP Lokantara ${ }^{1^{*}}$, NPG Suardana ${ }^{2}$, IW Surata ${ }^{3}$ and INS Winaya ${ }^{4}$ \\ ${ }^{1}$ Doctoral Study Program of Engineering Science, Faculty of Engineering, Udayana University \\ Kampus Sudirman, Denpasar-Bali, Indonesia. \\ 1,2,3,4 Study Program of Mechanical Engineering, Faculty of Engineering, Udayana University \\ Kampus Bukit Jimbaran, Badung-Bali, Indonesia \\ lokantara@unud.ac.id
}

\begin{abstract}
The purpose of this study was to determine the effect of alkali fiber treatment on the tensile strength of composites. The material in this study was recycled polypropylene from plastic beverage glass and lidah mertua fiber with a fiber length of $180 \mathrm{~mm}$, fiber treatment using $5 \% \mathrm{NaOH}$ and without treatment. Composite specimens were prepared using the hot press method at $170^{\circ} \mathrm{C}$ for 120 minutes. Tensile testing with the dimensions of the test specimen refers to ASTM D-638. The results of the test carried out the maximum tensile strength value of 71,606 $\mathrm{MPa}$ in fiber with $5 \%$ alkali treatment. The tensile strength of composites with alkali treatment increased $223 \%$ compared to the tensile strength without alkali
\end{abstract}

Keywords: recycled polypropylene, fiber treatment, lidah mertua fiber, tensile strength

\section{INTRODUCTION}

Waste production per day in Denpasar City increased from $3,507.67 \mathrm{~m}^{3}$ in 2014 to $3,719 \mathrm{~m}^{3}$ in 2017, an increase of 6\%. Inorganic waste production from $602.99 \mathrm{~m}^{3}$ in 2015 to $982.97 \mathrm{~m}^{3}$ in 2017 , increased by $63 \%$. In the national scope, the percentage of households that recycle waste is $1.2 \%$ and that burns waste is $66.8 \%$. Data for 2017-2018 in the city of Denpasar produced plastic waste by $13.6 \%$, and the production of plastic glass waste by $0.93 \%$. Plastic waste made from thermosetting polymers harms the environment because plastic waste cannot be degraded, causing $\mathrm{CO} 2$ emissions and sometimes toxic gases when the material is burned while plastic waste made from thermoplastic polymer materials, especially polypropylene types such as drinking glasses can be recycled and can be recycled reused [1]. To reduce the problem of plastic waste, it is necessary to apply the principle of 3R (Reduce, Reuse, Recycle), reduce which is the activity of reducing plastic products, reuse that is reusing plastic waste, and recycle is the activity of recycling plastic waste. One of the efforts to recycle plastic waste is to use it as a composite filler material. Several studies have been carried out by researchers about the use of recycled plastic waste as a composite matrix combined with reinforcement of several types of natural fibers. The advantages of natural fibers include easily extracted, lightweight, renewable natural resources, biodegradable in nature [2]. Several studies on recycled plastic waste reinforced plastic composites have been carried out, one of them is recycled polypropylene composite reinforced with reeds [3], palm fronds [4], kenaf [5,6], sisal [7-9], palm fibers [10], wood [11], coir [12-13], hemp [14]. Indonesia with a tropical climate, there are various types of plants with fiber that can be utilized, one of which is the lidah mertua (Sansevieria trifasciata). Lidah mertua commonly known as "snake plant" or "mother-in-law" is a species in the family Asparagaceae. Lidah mertua grows well all over the world and has many Sansevieria species [15]. Lidah mertua is a type of ornamental plant that is quite popular as an ornamental part of the house because this plant can grow in conditions with little water and lots of suns. Lidah mertua entered Indonesia around the 1980s with laurentii and trifasciata types. The fiber content in these plants is relatively strong, does not cause health problems when processed, is easy to obtain and is a renewable material. The availability of abundant plants with fiber content that can be used as a reinforcing material in polypropylene plastic waste recycling composites. 


\section{METHOD}

\subsection{MATERIAL}

Lidah mertua leaves were collected in Tumbakbayuh village, Mengwi sub-district, Badung District, Bali Province, Indonesia. The leaves were taken from the middle leaves with relatively the same length

\subsection{FIBER EXTRACTION PROCESS}

Lidah mertua leaves are collected and selected with the same relative length, as shown in Figure 1. The leaf midrib is mixed with a pipe before the water retting process is done, soaking in water for 7 days. After the water retting process the fibers are separated manually, then washed with running water until clean, as in Figure 2. The fibers are dried at ambient conditions for two days to reduce their water content, then stored in a waterproof plastic container.

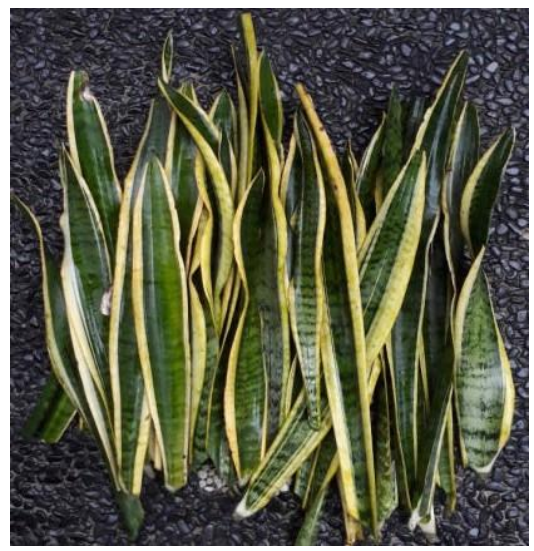

Fig. 1. Lidah mertua leaves

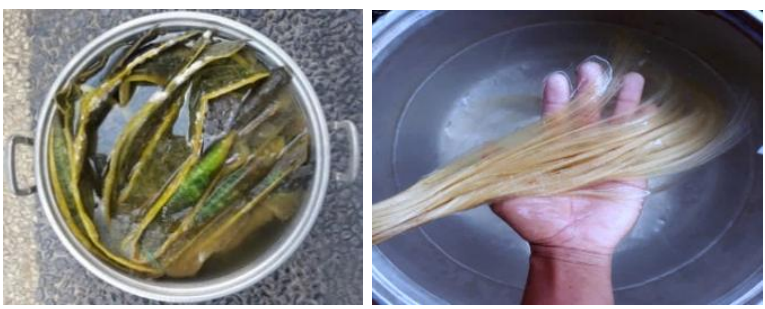

Fig. 2. Water retting process

Recycled polypropylene used is used in certain brands of mineral water drinks. Plastic cups are cut into small pieces, cleaned with running water, then dried with air to remove the water that sticks, shown in figure 3

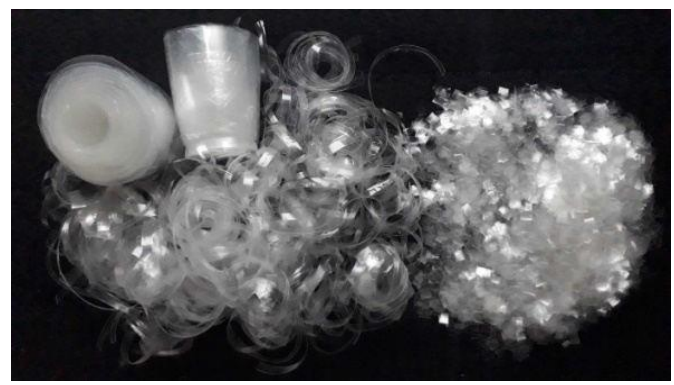

Fig. 3. Recycled polypropylene

\subsection{ALKALI TREATMENT}

Fibers pretreatment of the fiber using $\mathrm{NaOH}$ solution. The fiber is soaked in a $\mathrm{NaOH}$ solution with a concentration of $5 \%$ for 2 hours. The next process the fiber is rinsed in running water until clean then the $\mathrm{pH}$ of the immersion water is measured to normal $\mathrm{pH}$, then dried for 5 days, as shown in Figure 4.

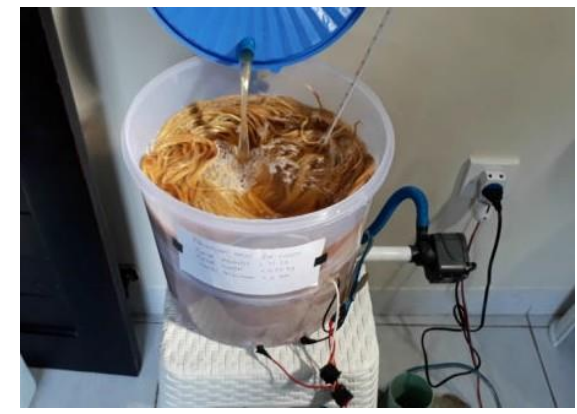

Fig. 4. Alkali treatment process

\subsection{FIBER DENSITY}

The density of fibers and polypropylene is measured using a pycnometer, as in figure 5 below

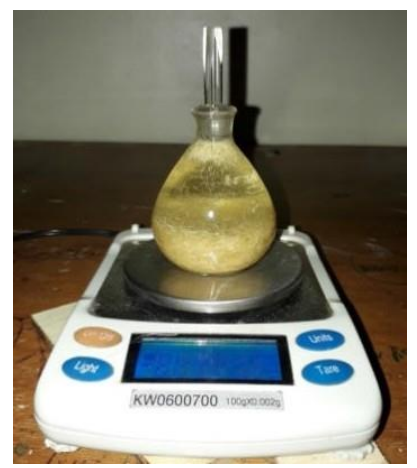

Fig. 5. Alkali treatment process

The formula to determines density:

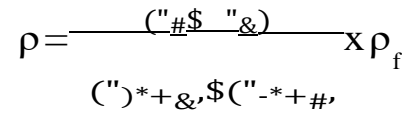




$$
\begin{aligned}
& \rho=\text { fiber density } \\
& \rho_{\mathrm{f}}=\text { fluid density } \\
& \mathrm{m}_{1}=\text { pycnometer mass } \\
& \mathrm{m}_{2}=\text { pycnometer mass }+ \text { fiber } \\
& \mathrm{m}_{3}=\text { pycnometer mass }+ \text { liquid } \\
& \mathrm{m}_{4}=\text { pycnometer mass }+ \text { liquid }+ \text { fiber }
\end{aligned}
$$

\subsection{COMPOSITE MANUFACTURING}

The composite manufacturing process by the hot press method, see in figure 6. Lidah mertua fiber with a length of $180 \mathrm{~mm}$ was used in this study at $35 \%$ fiber volume fraction. Pieces of plastic are sown first, then the fibers are arranged on top of the pieces of plastic in a uniform direction. Polypropylene pieces are placed on top. The mold is closed and given the pressure of 3 tons, the temperature is raised to $170^{\circ} \mathrm{C}$ and held for 2 hours. The mold is cooled using a fan airflow until it is cold, then the mold is opened.

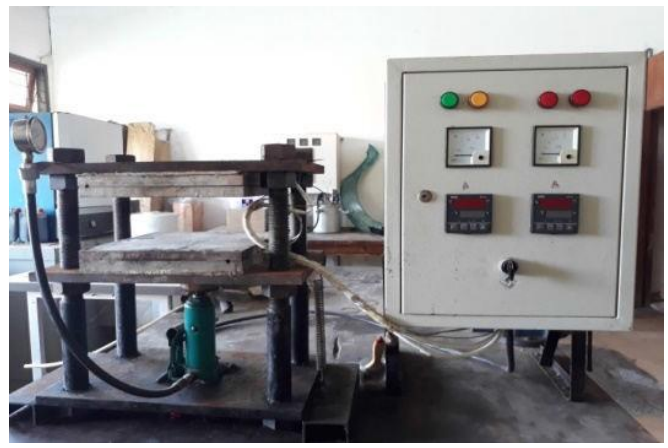

Fig 6. Hotpress machine

The results of composite printing can be seen in Figure 7, the dark color is the composite whose fiber gets $5 \% \mathrm{NaOH}$ treatment, while the lightcolored fibers are without treatment.

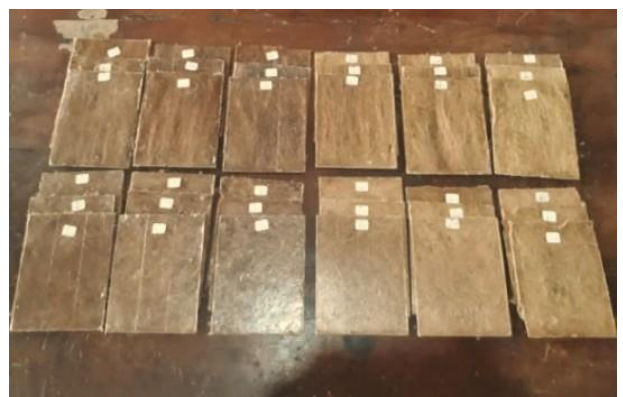

Fig. 7. Composite mold

The composite is then cut with a cutting tool to make the test specimen, as in figure 8 , below.

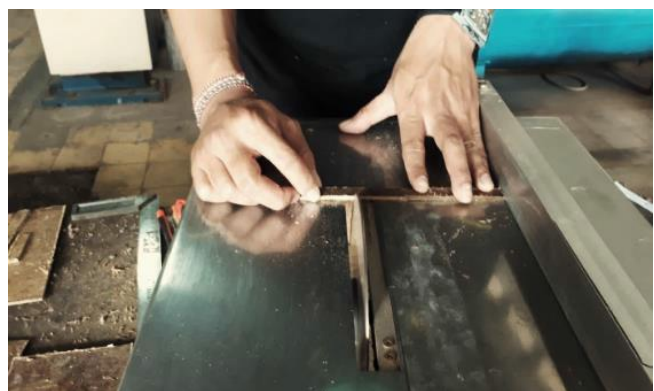

Fig 8. Cutting to make tensile test specimens

\subsection{TENSILE TEST}

The size of the tensile test specimen used with dimensions of length $165 \mathrm{~mm}$, width $12.7 \mathrm{~mm}$, thickness $3 \mathrm{~mm}$ by ASTM D-638.

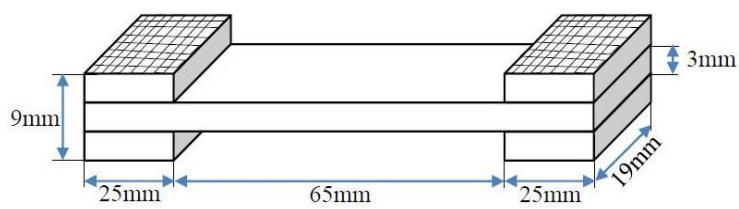

Fig. 9. Dimensions of tensile test specimens

In this study, two types of tests were carried out, composite specimens without alkali treatment, and composites whose fibers were treated with $5 \% \mathrm{NaOH}$. Composite tensile testing using the Tensilon RTG 1310 test machine was carried out at the Physics Lab of the University of Mataram, NTB.

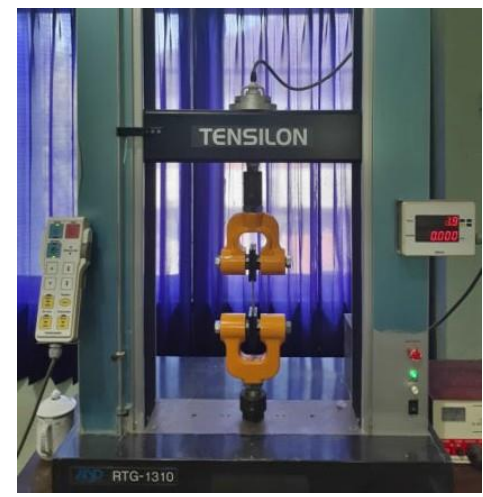

Fig.10. Tensile test machine

\section{RESULT AND DISCUSSION}

The results of the measurement of the density of Sansevieria trifasciata fibers without treatment and with $5 \% \mathrm{NaOH}$ treatment, as well as, the density of recycled polypropylene with 6 repetitions can be seen in Table 1

Table 1. Fibers and polypropylene density 


\begin{tabular}{cccc}
\hline & \multicolumn{3}{c}{ Density $\left(\mathrm{gr} / \mathrm{cm}^{3}\right)$} \\
\cline { 2 - 4 } Experiment & Polypropylene & $\begin{array}{c}\text { Fiber } \\
\text { without } \\
\text { alkali }\end{array}$ & $\begin{array}{c}\text { Fiber } \\
\text { with 5\% } \\
\text { NaOH }\end{array}$ \\
\hline 1 & 0,857 & 1,356 & 1,456 \\
2 & 0,831 & 1,365 & 1,468 \\
3 & 0,884 & 1,408 & 1,476 \\
4 & 0,895 & 1,419 & 1,458 \\
5 & 0,897 & 1,375 & 1,466 \\
6 & 0,895 & 1,398 & 1,466 \\
Average & $\mathbf{0 , 8 7 6}$ & $\mathbf{1 , 3 8 6}$ & $\mathbf{1 , 4 6 5}$ \\
\hline
\end{tabular}

can increase the bond between the matrix and the fiber, good bonding of the matrix and fiber can increase tensile strength because the load received by the composite is fully forwarded by the fiber without the slip [16]. This is supported by the SEM test results in Figures 12 and 13 below.

Sansevieria trifasciata fiber used in this study is a fiber with a straight orientation with a fiber length of $180 \mathrm{~mm}$. While the fiber volume fraction used is $35 \%$. Tensile test specimens are tested in the Lab. The Physics University of Mataram uses tensilon RTG 1310 mechanical test equipment. The test results are calculated using the following formula.

$$
\begin{aligned}
\qquad \mathrm{C}^{-} & \multicolumn{1}{c}{} \\
\sigma & =\text { Tensile strength }(\mathrm{Mpa}) \\
\mathrm{P} & =\text { Force }(\mathrm{N}) \\
\mathrm{A} & =\text { Surface area of fiber cross section }\left(\mathrm{mm}^{2}\right)
\end{aligned}
$$

Tensile stress data can be seen in Figure 11 below

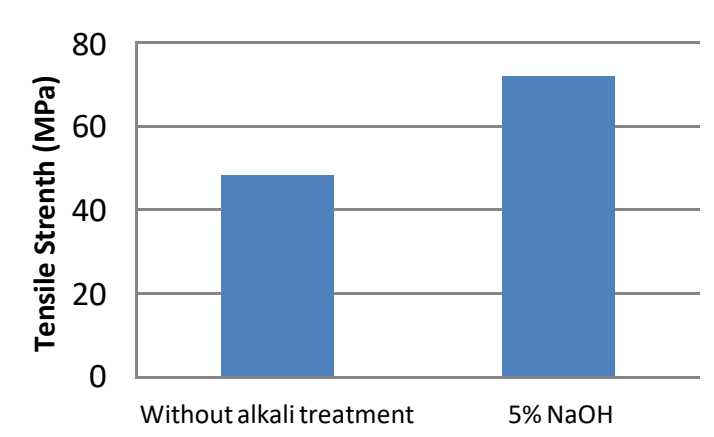

Fiber treatment

Fig. 11. Effect of fiber treatment on tensile stress

The highest tensile strength value is found in straight fiber with treatment that is equal to 71,606 $\mathrm{MPa}$ for straight fiber without treatment has a tensile strength of 48,052 MPa. An increase of $223 \%$ compared to the tensile strength without treatment. This can be caused by fibers with cleaner and rougher treatments because the lignin, wax, and impurities have been reduced so that it

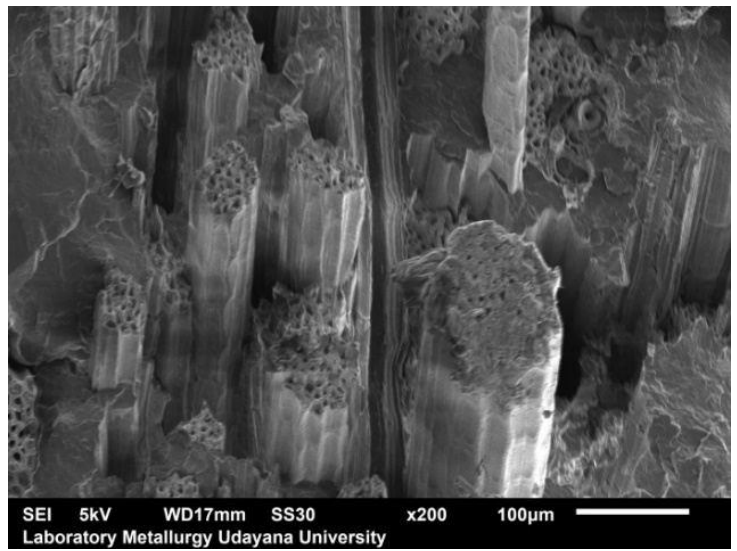

Fig. 12. SEM results of composites with $5 \% \mathrm{NaOH}$ fiber treatment

SEM test results for straight fiber composites with the treatment showed more even fiber fractures with the matrix. This indicates a good bond between the fiber and the matrix where the load received by the composite is held simultaneously between the matrix and the fiber without any slip so that the composite failure due to the strength limit of the fiber is not due to the slip between the fiber and the matrix.

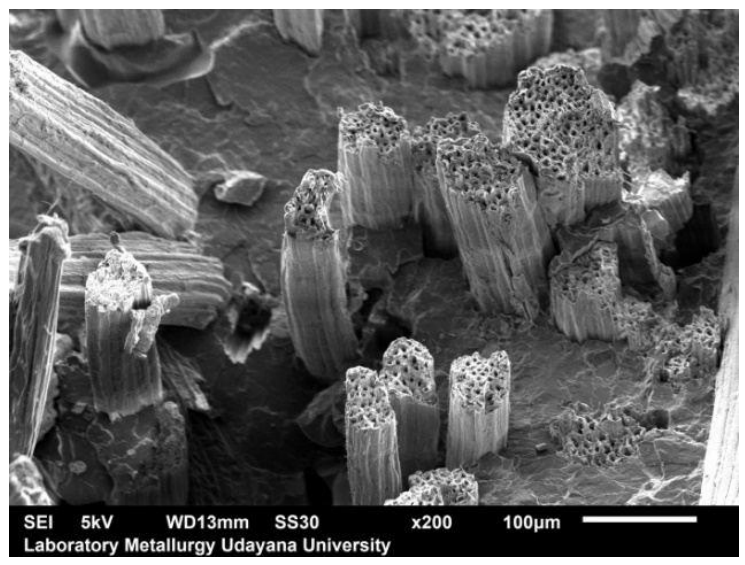

Fig. 13. SEM results of composites without alkali

SEM test results for straight fiber composites without $\mathrm{NaOH}$ treatment fiber fracture is dominated by pull out rather than flat fiber 
fracture with the matrix it shows the bond between the fiber and the matrix is not good so that the load is not received simultaneously on the fiber and the matrix due to slip so that tensile strength which is obtained is lower than the fiber with the treatment.

The results of the tensile strength of the composite with $5 \% \mathrm{NaOH}$ treatment amounted to $71,606 \mathrm{MPa}$ and the tensile strength without treatment amounted to $48,052 \mathrm{MPa}$. A significant increase of $223 \%$. This can happen because in a straight fiber variation all fibers contained in the composite specimen receive a load that is passed on to the fiber with minimal slip.

\section{CONCLUSION}

From the result and discussion above, it can be concluded that the lidah mertua fiber has a lighter density than glass fiber, so it can be used for light and environmentally friendly material applications. The treatment of lidah mertua fiber with $5 \% \mathrm{NaOH}$ alkaline solution for 2 hours was able to increase the tensile strength by $223 \%$ compared to untreated fibers. This happens because in straight fibers all fibers contained in the composite specimen receive a load which is passed on to the fiber with minimal slip

\section{ACKNOWLEDGMENT}

Special thanks to Prof. Ngakan Putu Gede Suardana who guided this research.

\section{REFERENCES}

[1] Subdirektorat Statistik Lingkungan Hidup. 2016. Statistik Lingkungan Hidup, Indonesia 2016. [e-book]. Jakarta: Katalog Badan Pusat Statistik 3305001 http://media.neliti.com/media/publications/4 8275-ID-statistik-lingkungan hidupIndonesia-2016.pdf

[2] Jawaid, M., and Abdul Khalil, H. P. S, Cellulosic/synthetic fiber reinforced polymer hybrid composites: A review. Carbohydrate Polym. 86: 1-18, 2011.

[3] A. N. Balaji, M. K. V. Karthikeyan \& V. Vignesh, Characterization of New Natural
Cellulosic Fiber From Kusha Grass, Int. J.Polym. Anal. Charact, 21, 29-39, 2016

[4] Wardani, L., M. Y. Massijaya, dan M. F. Machdie. Pemanfaatan limbah pelapah sawit dan Plastik Daur ulang (RPP) sebagai papan komposit plastik. Jurnal Hutan Tropis, 3 (1): 46-53, 2013

[5] Neng Sri Suharty, Hanafi Ismail, Kuncoro Diharjo, Desi Suci Handayani, and Maulidan Firdaus, Effect of Kenaf Fiber as a Reinforcement on the Tensile, Flexural Strength and Impact Toughness Properties of Recycled Polypropylene/Halloysite Composites, Procedia Chemistry, 253-258, 2016

[6] M.R.Ishak, Z. Leman, S.M. Sapuan A, M. M. Edeerozey and I. S. Othman, and Nmegbu, Mechanical Properties of kenaf bast and core fiber reinforced unsaturated polyester composites, IOP Conf. Series: Materials Science and Engineering 11: 1-6, 2010.

[7] Arun Kumar Gupta, Manoranjan Biswal, S.Mohanty, S.K. Nayak, Mechanical, Thermal Degradation, and Flammability Studies on Surface Modified Sisal Fiber Reinforced Recycled Polypropylene Composites. Journal Advances in Mechanical Engineering, 2012

[8] Sulawan Kaewkuk, Wimonlak Sutapun, Kasama Jarukumjorn, Effects of interfacial modification and fiber content on physical properties of sisal fiber/polypropylene composites, Composites Part B: Engineering, 45 (1), 544-549, 2013

[9] Rachasit Jeencham, Nitinat Suppakarn, Kasama Jarukumjorn, Effect of flame retardants on flame retardant, mechanical, and thermal properties of sisal fiber/polypropylene composites, Composites Part B: Engineering, 56, 249-253, 2014

[10] Tshwafo E. Motaung, Linda Z. Linganiso, Maya John, Rajesh D. Anandjiwala, The Effect of Silane Treated Sugar Cane Bagasse on Mechanical, Thermal and Crystallization Studies of Recycled Polypropylene. Materials Sciences and Applications 6, 724-733, 2015.

[11] Svetlana Butylina, Ossi Martikka \& Timo Kärki, Physical and Mechanical Properties of Wood-Polypropylene Composites Made with Virgin and/or Recycled Polypropylene, 
Polymer-Plastics Technology and Engineering, 50 (10), 1040-1046, 2011

[12] Mominul Haque, Nazrul Islam, Monimul Huque, Mahbub Hasan, Saiful Islam \& Sakinul Islam, Coir Fiber Reinforced Polypropylene Composites: Physical and Mechanical Properties, Advanced Composite Materials, 19 (1), 91-106, 2010

[13] Chun, Koay Seong, Salmah Husseinsyah, and Fatin Nasihah Azizi. Characterization and Properties of Recycled Polypropylene/Coconut Shell Powder Composites: Effect of Sodium Dodecyl Sulfate Modification. Polymer-Plastics Technology and Engineering 52 (3), 287-94, 2013

[14] Yulin Feng, Yuexin Hu, Guiyan Zhao, Jinghua Yin, Wei Jang Preparation and Mechanical Properties of High-Performance short Rami Fiber Reinforced Polypropylene Composite Journal of Applied Polymer Science, 122, 1564-1571, 2011

[15] Rwawiire, S. and B. Tomkova. Morphological thermal and mechanical characterization of sansevieria trifasciata fibers. Journal Of Natural Fibers, 12, 201210, 2015

[16] Nasmi Herlina Sari, I.N.G. Wardana, Y.S Irawan, E. Siswanto, "Characterization of the Chemical, Physical, and Mechanical Properties of $\mathrm{NaOH}$-treated Natural Cellulosic Fibers from Corn Husks, Journal of Natural Fiber, 15 (4), 545-558, 2018 